\title{
Analysis of Cultural Diversity in Preschool Education
}

\author{
* Asghar Abbas, PhD Scholar (Corresponding Author)
}

** Dr. Asad Abbas Rizvi, Assistant Professor

\begin{abstract}
Early childhood learning holds a great impact on children satisfaction, intensification, growth and core of education in this interval of life. In child development at early stage lot of activities related to family culture influencing growth and development. Learning throughout life is directly connected with these sorts of activities. In these activities culture base routine is most important for early years. In this age children have strong observational skills with their photo memory. The study was aimed to analyze cultural diversity among young learners, to recognize cultural differences in early childhood instructions and practices, to discover out social likenesses in early learning. It was quantitative research and descriptive research technique was used in this study. Institutions regarding preschool education were taken as population of research. Data was collected through multistage sampling technique. Data were analyzed through statistical techniques $t$ test and one-way ANOVA. Equal cultural diversity was concluded in both male and female early childhood learners. The analysis illustrated that instructive framework; academic capabilities of instructors, preschool learner's cultural background, teacher's emolument, cultural region, economical background contribute to cultural similarities and differences. The researcher recommends considering cultural diversity as basic perceptive of the teaching learning process.
\end{abstract}

Keywords: Pre schooling, Culture, Cultural Practices, Cultural Similarities, Cultural Differences Introduction

In the early life stages of learners, his/her attitude is developed. Several factors shape the attitude of learners. Educational institute is one of the primary factors that develop a specific attitude of learners. Culture is a combination of ways of living, talking, feeling, behaving, dealing, dressing, celebrating, and many other things (Saderman-Hall \& Rhomberg, 1995). Although every stage of the life of the learner is important but pre-schooling stage is the most crucial stage. Here a question may arise that whether preschool learner affects the culture or culture affects the growth of pre learner (Hedges, 2000; Wood, 2009). Another question may also arise that culture shapes the attitude of a learner or attitude of learners affects the culture. Preschool Education is the most important stage of the study that a learner goes through in their life (Heckman, 2000).

Delpit and Dowdy (2002) defines cultural practices is "the joint methods that groups of people have shaped to use and describe their atmosphere". Culture has a pivotal effect on the growth of preschool learners. Students behave what they observe, feel, and face (Siraj-Blatchford \& Sylva, 2004). Culture includes every minute detail a personal take throughout his/her social and cultural life (Taylor, 2009). These are the factors that shape the attitude of learners. Learning is to bring positive change in the behaviour of the learner. So, learning and culture, behaviour, and are interlinked (Banks, 2006).

Although thinking ability exists among preschool learners but usually at this stage of learning, the learner learns through imitation (Dewey, 1913). A preschool learner must learn many things to initiate the journey of his/her life. He/She must perform many tasks in his/her life. He/She takes guidance from every factor existing around him/her (Wade, 2001). So, his learning is mostly affected by the culture. The cognitive development of preschool learners is a very sensitive agenda of every nation. Nations also want to transmit their cultural heritage to the upcoming generation (Farquhar, 2003). It is the process of education which makes ensures the transmission of culture. That is why preschool learning is given the most priority and its sensitivity is felt everywhere (Lohmander, 2004).

\footnotetext{
* International Islamic University, Islamabad Email: asgharabbas55@gmail.com

** International Islamic University, Islamabad Email: drasad.rizvi@iiu.edu.pk
} 
In the current study, the researcher has analyzed the cultural diversity in preschool learners. For the conduct of this study, the researcher consulted the learners and teachers of preschool systems of different areas of Pakistan. The researcher analyzes that to what extent variations exist among male and female pre learners regarding cultural diversity. Researcher also analyzes that to what extent cultural similarities and dissimilarities exist among preschool learners. The researcher also analyzes the cultural diversity in preschool learners of different school systems and different regions.

\section{Research Objectives}

Research objectives are as follows:

1. To discover cultural similarities in preschool learners.

2. To discover cultural variations in preschool learners.

\section{Significance of the Research}

The research study may be facilitative for ECE learners and parents of learners to acknowledge the preschool learning.

It may be supportive to early learning stakeholders for revealing of the hurdles concerning the cultural diversity.

It may be productive for educational managers of early learners to keeping in mind the issues of cultural diversity.

\section{Research Design}

Quantitative research methodology preserves the assumption of an empiricist paradigm (Creswell, 2003). A descriptive research design was used for conducting of study.

\section{Population of the Research}

All the learners of preschool educational institutes associated with The Educators school system, Allied schools school system, and Dare e Arqam school system were part of the population.

\section{Sample of the Research}

\section{A) First Stage}

The researcher selected three educational systems' campuses and sub-campuses having preschool education across the four geographic areas of Pakistan through a purposive sampling technique.
B) Second Stage
C) Third Stage
Four early year learners were selected randomly from sampled institutions.

Table 1

Sample of Research Study

\begin{tabular}{ccc}
$\begin{array}{c}\text { First Stage } \\
\text { Regions }\end{array}$ & $\begin{array}{c}\text { Second Stage } \\
\text { Schools in No. }\end{array}$ & $\begin{array}{c}\text { Third Stage } \\
\text { learners in No. }\end{array}$ \\
\hline 4 & (Twelve schools from every region) & (Four learners from every school) \\
\hline
\end{tabular}

Instruments of research study

Data was collected through an observational checklist.

Table 2

Instruments of research study

\begin{tabular}{ccc}
\hline Instruments & Type of data & Source \\
\hline Observational checklist & Quantitative Data & Learners \\
\hline For &
\end{tabular}

For preschool students' observation, an observational checklist was developed. The purpose of the observation was to collect the responses of students related to cultural diversity existing in early year learners. An observational checklist was filled based on the response of students with the help of their most familiar class teacher and research assistant. The research assistant was trained under the requirements of the research study to fulfil the directions of data collection and the purpose of the study. Preschool teacher was also briefed completely regarding the purpose of the study. The students at the preschool level are supposed to familiar with their class teacher. The researcher and research assistant and teacher-guided the students time to time where they felt that students needed help. The session of observation was based on a time span of 45 minutes. 


\section{Data Collection}

The data was collected from sample school by researcher, co-researcher, and class teacher of preschool through observational checklist.

\section{Data Analysis}

\section{Table 3}

Cultural Diversity Students Distribution on the base of their gender

\begin{tabular}{lccc}
\hline Learners gender & $\boldsymbol{N}$ & Mean & $\boldsymbol{S D}$ \\
\hline Girls & 93 & 47.56 & 7.772 \\
Boys & 98 & 48.11 & 7.269 \\
\hline
\end{tabular}

Table one clarifies that boy's preschool learners were more culturally diverse than girls' preschool learners.

\section{Table 4}

Gender Vs Cultural Diversity

\begin{tabular}{cccccc}
\hline & \multicolumn{2}{c}{ Levene's Test } & \multicolumn{3}{c}{ t-Test } \\
\cline { 2 - 6 } & $\boldsymbol{F}$ & Sig. & $\boldsymbol{T}$ & $\boldsymbol{D f}$ & Sig. \\
\hline Equal variances Assumed & .389 & .533 & .508 & 189 & .612 \\
Equal variances not assumed & & & .507 & 186.350 & .613 \\
\hline
\end{tabular}

Table 4 revealed that there was no significant difference regarding cultural diversity among boys' preschool learners and female preschool learners $(p=0.612)$.

\section{Table 5}

Diversity in Culture and school systems

\begin{tabular}{lccc}
\hline & Df & $\boldsymbol{F}$ & Sig. \\
\hline Amongst Groups & 2 & 3.448 & .034 \\
Within Groups & 188 & & \\
Sum & 190 & & \\
\hline
\end{tabular}

It was found that there was a statistically significant cultural diversity concerning types of systems i.e. The Educators school system, Allied School system and Dar-e-Arqam school were different from each other based on cultural diversity $(p=0.034)$. To reveal this difference, the Post Hoc Tuckey test was run.

Table 6

School System vs. Cultural Diversity

\begin{tabular}{clcc}
\multicolumn{1}{c}{ School Name } & \multicolumn{1}{c}{ School Name } & Mean Difference & Sig. \\
& & & \\
\hline The Educators System & Allied School System & 3.08 & .067 \\
& Dar e Arqam School System & 3.19 & .046 \\
Allied Schools System & Dar e Arqam School System & .11 & .996 \\
\hline
\end{tabular}

Table 6 presented that statistical difference was seen between The Educators School System and Dar e ArqamSchool System regarding cultural diversity as $p=0.046$. It was revealed that there was no significant difference between Allied Schools System and Dar e ArqamSchool System regarding cultural diversity as $\mathrm{p}=.996$. Similarly there was no significant difference between The Educators and Allied Schools regarding cultural diversity as $\mathrm{p}=0.067$.

Table 7

Region of Schools vs Cultural Diversity

\begin{tabular}{cccc}
\hline & $\boldsymbol{D} \boldsymbol{f}$ & $\boldsymbol{F}$ & Sig. \\
\hline Amongst Groups & 3.0 & 5.97 & 0.001 \\
Within Groups & 187.0 & & \\
Sum & 190.0 & & \\
\hline
\end{tabular}

It was revealed that the region of school was culturally diverse $(p=.001)$. To reveal this difference, the Post Hoc Tuckey test was run. 
Table 8

Region of School vs. Cultural Diversity

\begin{tabular}{cccc} 
Region of School & Region of School & Mean Difference & Sig. \\
\hline \multirow{2}{*}{ Pothohar } & Central Punjab & .686 & .965 \\
& KP & $-5.182^{*}$ & .021 \\
\multirow{3}{*}{ Central Punjab } & Sind & -2.368 & .644 \\
KP & KP & $-5.867^{*}$ & .000 \\
& Sind & -3.054 & .293 \\
\hline
\end{tabular}

Outcomes of Table 6 uncovered a significant difference regarding cultural diversity amongst $\mathrm{KP}$ and Pothohar regions as $\mathrm{p}=0.021$ and KP and Central Punjab as $\mathrm{p}=0.000$. It was found that there was no statistically significant difference regarding cultural diversity concerning Regions of preschool learners i.e. Central Punjab and KP as $p=.000$. It was further revealed that there is no significant difference among Pothohaar and Central Punjab as $p=0.965$ and Sind and Pothohaar as $p=0.644$ and Central Punjab and Sind as $p=0.293$ and Sind and KP as $p=0.504$.

Table 9

Students age vs. Cultural Diversity

\begin{tabular}{lccc}
\hline & $\boldsymbol{D f}$ & $\boldsymbol{F}$ & Sig. \\
\hline Amongst Groups & 3.0 & 2.60 & 0.053 \\
Within Groups & 187.0 & & \\
Sum & 190.0 & & \\
\hline
\end{tabular}

It was found that there was no significant cultural diversity concerning the age group of students $(p=.053)$.

\section{Findings}

1. It was revealed that preschool boys were more culturally diverse than girl students.

2. Dar e Arqam school system showed more cultural diversity than other school systems.

3. A significant difference was observed regarding cultural diversity amongst KP and Pothohar regions and KP and Central Punjab regions. It was revealed that there was no significant difference regarding cultural diversity concerning Regions of preschool learners i.e. Central Punjab and KP, Pothohaar and Central Punjab, Central Punjab, and Sind, KP, and Sind.

4. No cultural diversity difference was observed concerning the age group of students.

\section{Discussions}

Educational experts support the unique and individualized values, strengths, and potential of each child and family. Effective early childhood education professionals give value to cultural differences, linguistic, abilities, and individual differences while studying about growth of preschool learners (Baldock, 2010).

The research was conducted to acknowledge cultural diversity among early year learners. Early education guidance has vital importance during learners early year's life. Culture is commonly having an impact on the infant's grooming. Result of cultural conduct like behaviour, way of dressing, way of eating, way of living, and way of thinking, lifestyle, affects priorities or preferences among young ones. In the current study, it has been attempted to search out cultural diversity in early age schooling.

The current study resulted that male preschool learners are more culturally diverse than females. The result of this study resembles the study of Bang (2015) who also resulted that male preschool learners show more cultural diversity. He stated that culture, learning, the natural world, and development are interlinked, and learner's intellectual social and moral development is affected by the natural world.

The current study revealed that different preschool systems affect the culture of pre learners. Geanne and associates (2017) revealed that educational institutes play a key role in designing and developing of a culture. Every school system has a specific culture and this institute adopts specific 
measures to transmit this culture. Lansford and associates (2016) and Levine (2007) state that pre learner's educational institutes are the hub of culture and developer of traditions. They explain that educational institutes are changing agents and introduce refined culture and traditions to preschool learners.

The current study revealed that cultural diversity exists among different regions of preschool learners. It was concluded that every region has its specific customs, traditions, and culture depending upon its location temperature, environment, landscape, language, religion, aesthetics, and concept of good and bad. Although with time, the world is progressing towards a multi-cultural society, but this new multi-cultural society will have to care about the culture of all ethnic groups (Garcia \& Garcia, 2012; Kangan \& Kauerz, 2012).

The current study revealed that preschool learners were culturally diverse during different age groups. The same has been elaborated by Ng and associate (2012) and Durand (2011). They explained that the preschool learners of different age differ based on their liking disliking, individual differences, and cognitive approach. With the growing age, pre learner's interest changes, variation occurs among their liking and disliking. But we cannot say that pre learner of a specific age group has a specific culture. Variations exist in the culture of a preschool learner of a specific age group. They also elaborated that parents, teacher and educational institute are the prominent factors which influence the culture of pre learners.

The above discussion shows that the results of the current study have a close resemblance to the studies conducted earlier. But the uniqueness of the current study is that it had covered all aspects of the cultural diversity of preschool learners and the researcher has tried to fill the gaps existing in previous studies related to the cultural diversity of preschool learners.

\section{Conclusions}

Conclusions drawn from the study are given below:

1. It was concluded that male preschool students were more culturally diverse than female students.

2. Cultural diversity was reported in ECE learners on the bases of the school system in which they are studying.

3. It was also concluded that cultural diversity exists among preschool learners of different regions.

4. No cultural diversity was reported in preschool learners based on their age group.

\section{Recommendation}

The researcher drew the following recommendations.

1. It is recommended to consider gender-based cultural diversity while executing the teachinglearning process.

2. All stakeholders of ECE should consider cultural diversity among ECE learners.

3. While designing and developing the ECE curriculum, cultural diversity must be considered.

4. It is also recommended to consider the phenomenon of cultural diversity in teachers training programs.

\section{References}

Bang, M. (2015). Culture, learning, and development and the natural world: The influences of situative perspectives. Educational Psychologist, 50(3), 220-233.

Baldock, P. (2010). Understanding cultural diversity in early years. Washington DC: SAGE Publications.

Banks, J. A. (2006). Cultural diversity and education: Foundations, curriculum, and teaching (5th ed.). Boston: Allyn and Bacon.

Creswell, J. W. (2009). Research design: Qualitative, quantitative and mixed methods approaches. London, UK: SAGE Publications, Inc.

Delpit, L., \& Dowdy, J. K. (2002). The skin that we speak: New York: Thoughts on the new press.

Dewey, J. (1913). Interest and Effort in Education. Boston: Houghton-Mifflin Co.

Durand, T. M. (2011). Latina mothers' cultural beliefs about their children, parental roles, and education: Implications for effective and empowering home-school partnerships. The Urban Review, 43(2), 255-278. 
Farquhar, S.-E. (2003). Quality teaching early foundations: Best evidence synthesis iteration. Wellington: Ministry of Education.

Garcia, E. E., \& Garcia, E. H. (2012). Understanding the language development and early education of Hispanic children.New York, NY: Teachers College Press.

Heckman, J.J. (2000). Policies to foster human capital. Chicago: University of Chicago Department of Economics.

Hedges, H. (2000). Teaching in early childhood: time to merge constructivist views so learning through play equals teaching through play. Australian Journal of Early Childhood, 25(4), 1621.

Lansford, J. E., Bornstein, M. H., Deater-Deckard, K., Dodge, K. A., Al-Hassan, S. M., Bacchini, D.,...Zelli, A. (2016). How international research on parenting advances understanding of child development. Child Development Perspectives, 10(3), 202-207.

Lohmander, M. K. (2004). The fading of teaching profession?Reform of early childhood teacher education in Sweden. Early Years, 24(1), 23-34, DOI: 10.1080/0957514032000179034

Ng, F. F., Tamis-LeMonda, C. S., Godfrey, E. B., Hunter, C. J., \& Yoshikawa, H. (2012). Dynamics of mothers' goals for children in ethnically diverse populations across the first three years of life: Social Development. The journal of analytical psychology, 21(4), 821-848.

Saderman-Hall, N., \& Rhomberg, V. (1995). The affective curriculum: Teaching the anti-bias approach to young children. Nelson, Canada: International Thomson.

Siraj-Blatchford, I. \& Sylva, K. (2004).Researching pedagogy in English pre-schools. British Educational Research Journal, 30(5), 713-730.

Taylor, L.S., \& Whittaker, C.R. (2009). Bridging multiple worlds: Case studies of diverse educational communities (2nd ed.). Boston: Pearson.

Wade, S. E. (2001). Research on importance and interest: implications for curriculum development and future research. Educational Psychology Review, 13(3), 243-261.

Wood, E. (2009). Developing a pedagogy of play. In A. Anning, J. Cullen, \& M. Fleer (eds), Early childhood education: Society and culture, $2^{\text {nd }}$ ed (pp.156-173).London: Sage. 